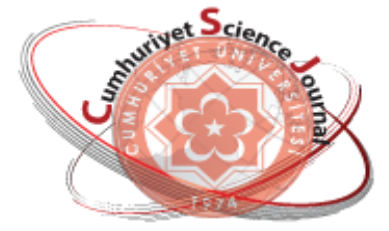

e-ISSN: $2587-246 X$

ISSN: $2587-2680$

\section{Cumburiy at Seience Journal esj}

Cumhuriyet Sci. J., Vol.40-2 (2019) 414-423

\title{
Hydrogen generation by Rhodobacter sphaeroides O.U.001 using pretreated waste barley
}

\author{
Gökhan KARS ${ }^{1^{*}}$ (D), Ayça EMSEN ${ }^{2}$ iD \\ ${ }^{I}$ Necmettin Erbakan University, Faculty of Science, Molecular Biology and Genetics Department, Konya, \\ TURKEY \\ ${ }^{2}$ Selçuk University, Faculty of Medicine, Department of Pediatric Immunology, Konya, TURKEY \\ Received: 08.02.2019; Accepted: 24.05.2019 \\ http://dx.doi.org/10.17776/csj.524612
}

\begin{abstract}
In the present study, valorization of waste barley by producing hydrogen $\left(\mathrm{H}_{2}\right)$ and 5-aminolevulinic acid (5-ALA) using Rhodobacter sphaeroides O.U.001 was aimed. Firstly, $3 \%$ (w/v) waste barley hydrolysate was prepared by treating $3 \mathrm{~g}$ of powdered waste barley with $\mathrm{H}_{2} \mathrm{SO}_{4}$ in a total volume of $100 \mathrm{~mL}$ mixture and then autoclaving this mixture at $121^{\circ} \mathrm{C}$ for $30 \mathrm{~min}$. Upon generation of fermentable simple sugars by pretreatment and analytical examination of the hydrolysate in terms of ammonium content, element composition and light transmittance, various types of growth media containing various concentrations of sugar $(5-6-7-8 \mathrm{~g} / \mathrm{L})$ were prepared. The cells were cultivated in these media under photo-heterotrophic conditions which favor $\mathrm{H}_{2}$ and 5-ALA generations. $\mathrm{pH}$ changes, growth, $\mathrm{H}_{2}$ production and 5-ALA generation were monitored in the media. The results showed that all the media prepared from $3 \%(\mathrm{w} / \mathrm{v})$ waste barley hydrolysate sustained the cell growth appreciably. The highest $\mathrm{OD}$ value $\left(\mathrm{OD}_{660}: 1.71\right)$ was attained when using $8 \mathrm{~g} / \mathrm{L}$ sugar. Furthermore, biological $\mathrm{H}_{2}$ evolution was seen in each bioreactor. In particular, the highest hydrogen accumulation $\left(0.29 \mathrm{~L} \mathrm{H}_{2} / \mathrm{L}\right)$ was achieved in $6 \mathrm{~g} / \mathrm{L}$ sugar-containing medium. However, 5-ALA was not detected in any of the media. To conclude, considerable cell growth and biological hydrogen production was achieved using $3 \%(\mathrm{w} / \mathrm{v})$ waste barley hydrolysate under the conditions tested but there was no detectable 5-ALA generation.
\end{abstract}

Keywords: Biological hydrogen, 5-aminolevulinic acid, Rhodobacter sphaeroides, waste barley.

\section{Ön işlemden geçirilmiş atık arpa kullanarak Rhodobacter sphaeroides O.U.001 ile hidrojen üretimi}

Özet. Bu çalışmada, Rhodobacter sphaeroides O.U.001 kullanılarak hidrojen $\left(\mathrm{H}_{2}\right)$ ve 5-aminolevulinik asitin (5-ALA) üretilmesi ile atık arpa'nın değerlendirilmesi hedeflendi. Öncelikle, $3 \mathrm{~g}$ toz halindeki atık arpa $\mathrm{H}_{2} \mathrm{SO}_{4}$ ile karıştırılarak $100 \mathrm{~mL}$ toplam hacimde karışım elde edildi ve sonrasında bu karışım $121{ }^{\circ} \mathrm{C}^{\prime}$ de 30 dakika boyunca otoklavlanarak \% 3'lük $(\mathrm{a} / \mathrm{h})$ atık arpa hidrolizatı hazırland1. Fermente edilebilir basit şekerlerin önişlem ile ortaya çıkarılması ve hidrolizatın amonyum muhtevası, element bileşimi ve 1şık geçirgenliği bakımından analitik olarak incelenmesinin ardından, farklı şeker konsantrasyonlarına sahip çeşitli büyüme ortamları (5 - 6 - 7 - $8 \mathrm{~g} / \mathrm{L}$ ) hazırlandı. Hücreler bu ortamlarda $\mathrm{H}_{2}$ ve 5-ALA yapımlarını destekleyen foto-heterotrofik koşullar altında çoğaltıldı. Ortamlardaki $\mathrm{pH}$ değişimleri, büyüme, hidrojen üretimi ve 5-ALA üretimi izlendi. Sonuçlar, \% 3'lük $(\mathrm{a} / \mathrm{h})$ atık arpa hidrolizatından hazırlanan tüm ortamların hücre büyümesini önemli ölçüde desteklediğini gösterdi. En yüksek OD değeri (OD660: 1.71) 8 g/L şeker kullanılarak elde edildi. Ayrıca, her bir biyoreaktörde biyolojik $\mathrm{H}_{2}$ üretimi gözlemlendi. Özellikle, en yüksek hidrojen birikimi

\footnotetext{
* Corresponding author. Email address: gkars@erbakan.edu.tr

http://dergipark.gov.tr/csj $\quad$ C) 2016 Faculty of Science, Sivas Cumhuriyet University
} 
(0.29 $\left.\mathrm{L} \mathrm{H}_{2} / \mathrm{L}\right), 6 \mathrm{~g} / \mathrm{L}$ şeker içeren ortamda elde edildi. Ancak, hiçbir ortamda 5-ALA tespit edilmedi. Sonuç olarak, test edilen koşullar altında \% 3'lük (a/h) atık arpa hidrolizatı kullanılarak önemli miktarda hücre büyümesi ve biyolojik hidrojen üretimi sağland1, ancak saptanabilir miktarda 5-ALA üretimi yoktu.

Anahtar Kelimeler: Biyolojik hidrojen, 5-aminolevulinik asit, Rhodobacter sphaeroides, atı arpa.

\section{INTRODUCTION}

Currently, there is increasing energy demand in the world and it is primarily supplied from the fossil-based fuels. However, it is generally recognized that the use of fossil-based fuels has negative impacts on environment. Sulfur oxides $\left(\mathrm{SO}_{\mathrm{x}}\right)$, carbon monoxide $(\mathrm{CO})$, nitrogen oxides $\left(\mathrm{NO}_{\mathrm{x}}\right)$, and carbon dioxide $\left(\mathrm{CO}_{2}\right)$ are the main pollutant gasses emitted as a consequence of the use of fossil-based fuels [1, 2]. For instance, while $\mathrm{CO}_{\mathrm{x}}$ emissions cause greenhouse effect, $\mathrm{SO}_{\mathrm{x}}$ and $\mathrm{NO}_{\mathrm{x}}$ emissions lead to acid rains. Moreover, these emissions might also cause serious health problems. Therefore, alternative and clean energy sources need to be developed to alleviate these environmental and health problems.

There are several alternative renewable and sustainable sources like geothermal energy, hydropower, solar energy, wind energy and biomass energy. Hydrogen can be considered as an energy carrier since there is no hydrogen source in nature but rather it is produced through biological and non-biological means [3, 4]. If hydrogen could be produced in a renewable and sustainable way, it can partially meet the world's energy demand. In our country, there are also sustainable and renewable sources for the generation of hydrogen and considerable amount of electricity could potentially be generated from the hydrogen produced [5]. Moreover, when used as a fuel, it does not produce any toxic chemicals. Biological hydrogen production occurs mainly by dark fermentation and photo-biological processes. In some processes, a combination of two was realized and called as two-stage hydrogen production method [6]. In biological hydrogen processes, the microorganisms take role and the responsible enzymes are hydrogenases and nitrogenases [7]. There are various types of these enzymes in microorganism [7, 8]. Photo fermentative hydrogen production is mainly performed by purple non-sulfur (PNS) bacteria. The representatives of them could be listed as Rhodopseudomonas palustris (Rps. palustris), Rhodospirullum rubrum (Rsp. rubrum), Rhodobacter capsulatus ( $R$. capsulatus) and Rhodobacter sphaeroides (R. sphaeroides). The responsible enzyme in PNS bacteria is nitrogenase and hydrogen production is an inherent character of the enzyme [7]. Under anoxic conditions and nitrogen limitations, the hydrogen is evolved at the expense of ATP using light energy [7, 8]. PNS bacteria are versatile in that they can grow under different physiological conditions and they can produce various valuable chemicals like 5aminolevulinic acid (5-ALA), poly-hydroxy butyrate (PHB) and vitamin $\mathrm{B}_{12}$ [9-13]. In a recently developed concept called biorefinery, more than one product (more than one fuel or fuel and value-added chemicals) is produced in the same bioprocess [12-16]. The logic behind this approach is to maximize the benefit from the biomass. In this way, cost-efficient bioprocesses will be developed. Kars et al. [12] reported the production of 5-ALA $(23 \mathrm{mM})$ and hydrogen (1.01 $\left.\mathrm{L} \mathrm{H}_{2} / \mathrm{L}\right)$ in the same bioprocess from sugar beet molasses.

In biological hydrogen production processes, different types of carbon sources could be used [17]. Industrial waste streams, agricultural and forestry lignocellulosic materials could effectively be used as substrate in the biological hydrogen production processes $[12,13,17]$. The selected carbon source should be cheap, found in large amount, easily fermentable by microbe and nontoxic to the cells. The case of using lignocellulosic biomass, the pretreatment of biomass is of great importance to produce useable simple sugars and organic acid. The basic pretreatment methods may be listed as mechanical, biological, chemical and physical techniques [18]. The motivation behind 
this study is to find cheap and accessible feedstock for biological hydrogen and 5-ALA productions. For this purpose, waste barley was chosen, pretreated and used as carbon source. In the present study, $3 \%(\mathrm{w} / \mathrm{v})$ waste barley hydrolysate was obtained. The growth media containing various quantities of sugar $(5,6,7$ and $8 \mathrm{~g} / \mathrm{L}$ ) were prepared using this hydrolysate. And, the formation of hydrogen and 5-ALA by $R$. sphaeroides O.U.001 in the bioreactors was monitored.

\section{MATERIAL AND METHOD}

\subsection{The microbial strain and its cultivation conditions}

In this study, R. sphaeroides O.U. 001 whose DSM number is 5864 was chosen for both photobiological hydrogen and 5-aminolevulinic acid productions. The medium used for the general maintenance of this bacterium was Biebl and Pfennig minimal medium [19]. One liter of minimal medium includes $\mathrm{K}_{2} \mathrm{HPO}_{4}(0.5 \mathrm{~g})$, $\mathrm{MgSO}_{4} \cdot 7 \mathrm{H}_{2} \mathrm{O}(0.2 \mathrm{~g})$, DL-Malic acid (2 g), $\mathrm{Na} \cdot$ Glutamate $\cdot \mathrm{H}_{2} \mathrm{O} \quad(0.37 \mathrm{~g}), \quad \mathrm{NaCl}(0.4 \mathrm{~g})$, $\mathrm{CaCl}_{2} \cdot 2 \mathrm{H}_{2} \mathrm{O}(0.05 \mathrm{~g})$, trace element solution $(0.05$ $\mathrm{mL}$ from 20X stock solution), $\mathrm{FeSO}_{4}(1 \mathrm{~mL}$ from $2 \mathrm{X}$ stock solution) and vitamin solution $(0.05 \mathrm{~mL}$ from 20X stock solution). One liter of $20 \mathrm{X}$ concentrated stock trace element solution includes $\mathrm{Na}_{2} \mathrm{MoO}_{4} \cdot 2 \mathrm{H}_{2} \mathrm{O}(40 \mathrm{mg}), \mathrm{NiCl}_{2} \cdot 6 \mathrm{H}_{2} \mathrm{O}(20 \mathrm{mg})$, $\mathrm{CuCl}_{2} \cdot 2 \mathrm{H}_{2} \mathrm{O}(2 \mathrm{mg}), \mathrm{CoCl}_{2} \cdot 6 \mathrm{H}_{2} \mathrm{O}(200 \mathrm{mg})$, $\mathrm{H}_{3} \mathrm{BO}_{3}(60 \mathrm{mg}), \mathrm{MnCl}_{2} \cdot 4 \mathrm{H}_{2} \mathrm{O}(100 \mathrm{mg}), \mathrm{ZnCl}_{2}(70$ $\mathrm{mg})$ and $\mathrm{HCl}(0.675 \mathrm{~mL}$ from $\%$ 37). $2 \mathrm{X}$ concentrated $\mathrm{FeSO}_{4}$ solution was prepared by adding $0.02 \mathrm{~g}$ of $\mathrm{FeSO}_{4}$ into $10 \mathrm{~mL}$ of $\mathrm{dH}_{2} \mathrm{O}$. One liter of $20 \mathrm{X}$ concentrated vitamin stock solution contains Thiamin $(500 \mathrm{mg}$ ), Nicotinic acid or Niacin $(500 \mathrm{mg})$ and Biotin $(15 \mathrm{mg})$. The trace elements solution and $\mathrm{FeSO}_{4}$ solution were sterilized by autoclave while vitamin element solution was sterilized through micro filtration since vitamins were heat-labile. The trace elements solution and $\mathrm{FeSO}_{4}$ solution were separately autoclaved and added to the basal media to prevent possible precipitations such as calcium phosphate precipitate. When solid media were needed, $1.5 \%$ agar was used in minimal media. $55 \mathrm{ml}$ glass bottles were used as bioreactors. The incubation temperature for the cultures was $29{ }^{\circ} \mathrm{C}$ and the light energy was provided by incandescent lamps $(100 \mathrm{~W})$. The intensity of the light bioreactor surface was circa $775 \pm 25$ lux. For general purposes, either aerobic or anaerobic condition was used.

\subsection{Pretreatment of waste barley}

$R$. sphaeroides is a versatile bacterium since it has the capability to utilize a wide variety of substrate as a source carbon $[12,20,21]$. However, the waste materials and lignocellulosic biomass should be pretreated to decompose the complex biomaterials into its monomers so that it could be utilized by the PNS bacteria. In the present study, waste barley was utilized as carbon source so that a cost-efficient hydrogen production process could be achieved. Firstly, $3 \mathrm{~g}$ of powdered waste barley was dissolved in certain amount of $\mathrm{dH}_{2} \mathrm{O}$ after which the $\mathrm{pH}$ of the concoction was set to 3 by adding $\mathrm{H}_{2} \mathrm{SO}_{4}$ before completion of the final volume to $100 \mathrm{~mL}$. The acid hydrolysis of waste barley $(3 \% \mathrm{w} / \mathrm{v})$ was performed by autoclaving this mixture at $121{ }^{\circ} \mathrm{C}$ for $30 \mathrm{~min}$. To remove the insoluble components, the suspension was spun at high speed $(9418 \mathrm{x} \mathrm{g})$ for about $10 \mathrm{~min}$ and then the liquid part above the pellet was filtered (Whatman Grade No: 41) to eliminate remaining insoluble particles. After completion of pretreatment process, the neutralization of the hydrolysate to $\mathrm{pH}: 7$ was done by $\mathrm{NaOH}$ addition. Upon neutralization, color of the hydrolysate became darker and some precipitates were formed. These were removed by re-centrifugation of the hydrolysate at $9418 \mathrm{x} \mathrm{g}$ for $10 \mathrm{~min}$ and then the amounts of total sugar, organic acids, total phenol and ammonium were analyzed.

\subsection{Analytical methods}

Many factors like a type of carbon source [20], presence of ammonia [22] and existence of necessary elements such as molybdenum and iron [23] influence biological hydrogen production. These factors exert their effect either directly on the nitrogenase enzyme or on the selected PNS bacterium. For this reason, waste barley 
hydrolysate was analyzed in terms of these aspects in order to prepare a suitable medium for biological hydrogen production. Acid-phenol spectrophotometric method applied for the determination of total simple sugar concentration of the waste barley hydrolysate [24]. First of all, a series of samples with pre-determined sugar concentrations were prepared and then their spectrophotometric measurements were done. After the graph was drawn, the unknown sample concentration was calculated by interpolation. After knowing the sugar content of the hydrolysate, 4 different culture media were prepared so as to contain 5, 6, 7 and $8 \mathrm{~g} / \mathrm{L}$ sugar concentration from $\% 3$ waste barley hydrolysate. The total ammonium ion content of the hydrolysate was found out with the use of an ammonium test kit (Norateks, Turkey). For this, 1 $\mathrm{mL}$ of barley hydrolysate was put into a glass tube and mixed with $4 \mathrm{~mL}$ of $\mathrm{dH}_{2} \mathrm{O}$. Then, 2 drops from the $\mathrm{NH}_{4}-1$ solution and 4 drops from the $\mathrm{NH}_{4}-2$ solution were put onto the diluted hydrolysate in order. The suspension was held at room temperature (RT) for $5 \mathrm{~min}$. for the formation of color. Finally, the color of the suspension was matched with the identical reference color on the manual to find out the ammonium concentration. The elements found in the $3 \%$ barley hydrolysate were identified by inductively coupled plasma mass spectrometry (ICP-MS, Perkin Elmer elanDRC-e, USA).

The produced hydrogen was collected in graduated glass tubes by water displacement method and purity of collected gas was measured by gas chromatography (GC, Agilent, 6890N). Supelco carboxen 1010 column and thermal conductivity detector were used in GC. The argon gas was utilized as carrier gas and the flow rate was set to $22.3 \mathrm{~mL} / \mathrm{min}$. The temperature of detector, injector and oven was adjusted to 170 ${ }^{\circ} \mathrm{C}, 160{ }^{\circ} \mathrm{C}$ and $140{ }^{\circ} \mathrm{C}$, respectively. The amount of 5-ALA in media was quantified by a spectrophotometric technique [25] and explained in detail in [26]. Similar to other methods mentioned above, 8 samples having predetermined amounts of 5-ALA were first made and then their spectrophotometric measurements were performed. Afterward, the quantities of 5ALA in the studied samples were calculated from the graph.

\subsection{Media preparation and culture conditions}

For the hydrogen and 5-ALA productions, four kinds of medium with various sugar concentrations $(5,6,7$ and $8 \mathrm{~g} / \mathrm{L})$ were made from $\% 3$ barley hydrolysate. The contents of the 5ALA and hydrogen production media were same as the contents of the Biebl and Pfennig minimal medium except that glutamate, malate and $\mathrm{NaCl}$ were not added since barley hydrolysate contains sufficient amount of carbon, nitrogen and $\mathrm{NaCl}$ sources. After putting all the ingredients of the medium into the bioreactors ( $55 \mathrm{~mL}$ glass bottles), the $\mathrm{pH}$ of the bioreactors was adjusted to 7 and sterilized by autoclaving. The sterile vitamin solution was then added into the bioreactors aseptically. The cultures were made anoxic by flushing with argon gas for $3 \mathrm{~min}$. The photoheterotrophic growth mode was provided by incubating the cultures under an illumination of $100 \mathrm{~W}$ incandescent lamps providing circa $775 \pm$ 25 lux on the surface of the bioreactors.

\subsection{Statistical analysis}

In this study, $\mathrm{pH}$, growth and hydrogen production experiments were performed in duplicate. Standard deviations from the mean values were calculated. The error bars were inserted into the graphs.

\section{RESULTS AND DISCUSSION}

\subsection{The analytical features of barley hydrolysate}

The quality of barley used in this study is low and it cannot be used as human food. The percentages of fat, protein, and starch in barley were determined previously and found to be $2.45 \pm$ $0.035,11.19 \pm 0.46$ and $37.5 \pm 0.49$, respectively [26]. Especially, the starch content of the waste barley was almost half of the normal quality barley. In the present study, hydrolysate was prepared as $3 \%(\mathrm{w} / \mathrm{v})$ as opposed to our previous study where $9 \%(\mathrm{w} / \mathrm{v})$ hydrolysate was used [13]. Therefore, the content of $3 \%$ (w/v) hydrolysate 
was different from $9 \%(\mathrm{w} / \mathrm{v})$ hydrolysate. After acid hydrolysis, the sugar content of the $3 \%(\mathrm{w} / \mathrm{v})$ barley hydrolysate was found to be $11.58 \mathrm{~g} / \mathrm{L}$. Then, 4 different media with various concentrations of sugars $(5,6,7$ and $8 \mathrm{~g} / \mathrm{L})$ were made from this barley hydrolysate. PNS bacteria could efficiently use glucose [27] and sucrose [12] for the generation of hydrogen. Moreover, type and composition of substrate were told to strongly influence both the hydrogen production and biomass accumulation [28]. In the present study, considerable amount of simple sugars was obtained after acid hydrolysis of waste barley. Therefore, it was shown that $3 \%$ (w/v) waste barley hydrolysate could be used as carbon source for R. sphaeroides O.U.001.

The ammonium content of the medium utilized for the generation of hydrogen influence the hydrogen generation ability of microorganism significantly since above $2 \mathrm{mM}$ concentration, the ammonium suppresses the nitrogenase enzyme resulting in the cessation of hydrogen evolution [22]. The ammonium content of the $3 \%(\mathrm{w} / \mathrm{v})$ hydrolysate was found to be $0.139 \mathrm{mM}$ which is below suppressive concentrations. After preparation of the media with different concentrations of sugar, the ammonium concentrations turned into $0.060 \mathrm{mM}, 0.072 \mathrm{mM}$, $0.084 \mathrm{mM}, 0.096 \mathrm{mM}$ in the media having initial sugar quantities of $5,6,7$ and $8 \mathrm{~g} / \mathrm{L}$ culture, respectively. These ammonium concentrations are far below the suppressive concentration; therefore, these media are suitable for the production of biological hydrogen.

It is known that elements such as iron and molybdenum are needed for the proper functioning of Mo-nitrogenase enzyme and hydrogen generation is mediated by this enzyme in R. sphaeroides O.U.001 [23]. In this context, the element composition of the $3 \%(\mathrm{w} / \mathrm{v})$ barley hydrolysate was found out by ICP-MS. In the hydrolysate, the analyzed elements and their quantities were (mg/L); B (0.449), $\mathrm{Cr}(0.052), \mathrm{Mn}$ (0.4), Fe (0.153), Co (-), Ni (-), Cu (0.05), Zn (0.227), Mo (0.003), Al (0.041), Ca (13.405), Mg (33.7), Na (>800), K (>400). Since sufficient amount of $\mathrm{Na}$ is present in the hydrolysate, $\mathrm{NaCl}$ was not added to the media. The other significant factor which also affects the hydrogen generation capability of microorganisms is the presence of high amount of phenols in the waste materials which are going to be used as substrate. For instance, the quantity of whole phenol $(1.9 \mathrm{~g} / \mathrm{L})$ was found to be at the toxic level in olive oil mill wastewater (OOMW) [29]. Therefore, OOMW could only be used as substrate after dilution with water for hydrogen production [30]. Total amount of phenolic substances in barley was found as $10.13 \mathrm{mg}$ GAE/g barley in our previous study [13]. The overall amount of phenol in the hydrolysate is significantly lower than that in OOMW. After preparation of the media by diluting with $\mathrm{dH}_{2} \mathrm{O}$, the quantity of phenols becomes much lower in the culture media. Therefore, waste barley hydrolysate is also suitable for hydrogen production in terms of total phenol content.

Another important parameter which should be considered for bio-hydrogen generation processes is the availability of sufficient energy in the form of light to the cells in the bioreactor. According to Uyar et al. [31], invisible light (infrared) at which the bacteriochlorophyll a shows the maximal absorption is more effective than the visible light where the carotenoid has absorption maxima. In this context, in order to see the transmittance of the barley hydrolysate, the $\%$ transmittance of barley hydrolysate at infrared region (800 and 860 $\mathrm{nm})$ was measured and it was found that the $\%$ transmittance of each media was above $\% 90$. The suitability of the barley hydrolysate in terms of light transmittance was also demonstrated.

\section{2. $\mathrm{pH}$ changes and bacterial growth}

Several media with various sugar concentrations $(5,6,7$, and $8 \mathrm{~g} / \mathrm{L})$ were made from $\% 3$ barley hydrolysate. After $10 \%$ inoculation into $45 \mathrm{~mL}$ fresh media, $50 \mathrm{~mL}$ of cultures were obtained and incubated under light. $\mathrm{pH}$ and the turbidity of the cultures were followed at certain time intervals (Figure 1 and Figure 2). $\mathrm{pH}$ of the medium is mainly dependent on the type carbon source and it 
is crucial for biological hydrogen production [32]. Even though the preliminary $\mathrm{pH}$ values of the cultures were adjusted to 7 , they dropped to 6.6 after inoculation of bacteria and incubation for about $32 \mathrm{~h}$ (Figure 1). Then, the $\mathrm{pH}$ of the cultures rose back to 7 after $23 \mathrm{~h}$ incubation. The $\mathrm{pH}$ of the media remained almost the same at around 7 until 175. h. Afterward, a slight increase (pH: 7.23) occurred in especially $5 \mathrm{~g} / \mathrm{L}$ sugar-containing medium. There were no significant changes in the $\mathrm{pH}$ of the other media. As a general tendency, the $\mathrm{pH}$ of the media followed a similar pattern and did not change significantly during the bioprocess. This result shows that the buffering capacity of phosphate buffer used in this study is high enough to resist the $\mathrm{pH}$ changes due to the metabolism of microorganisms. This uniform $\mathrm{pH}$ provides the bacteria with a suitable environment for hydrogen production.

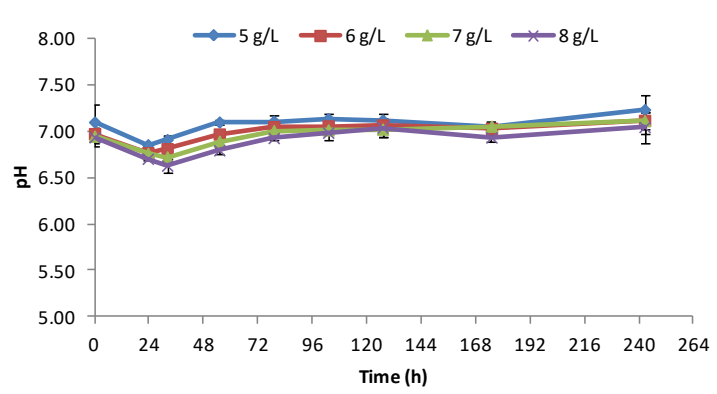

Figure 1. The $\mathrm{pH}$ changes during the growth of $R$. sphaeroides O.U.001. The experiment was done duplicate and standard deviations were added.

One of the aims is to find the optimal amount while using biomass as carbon source for bacterial growth. The use of high amount of hydrolysate might be toxic to the cells due to the ingredients of hydrolysate such as phenols or it might prevent light transmission in the bioreactor. Furthermore, the lower concentrations might be inadequate to sustain cell growth. For this reason, the growth of $R$. sphaeroides O.U.001 in the cultures having various concentrations of sugar was followed by taking spectrophotometric measurements periodically. In this way, the suitability of selected concentrations $(5,6,7$ and $8 \mathrm{~g} / \mathrm{L})$ in order to sustain bacterial growth was assessed. In the present study, relatively lower quantities of waste barley hydrolysate were used when compared to our previous study [13]. As shown in Figure 2, comparable OD values were attained when compared to our previous studies [13, 23]. A rapid rise in turbidity continued until 79 . h. and then the rate of increase slowed down. The maximal OD values were $1.25,1.44,1.50$ and 1.71 in the media having initial sugar concentrations of 5, 6, 7 and 8 $\mathrm{g} / \mathrm{L}$ cultures, respectively. The higher the sugar concentration, the higher the OD value (Figure 2). Demiriz et al. [33] used acetate as carbon source to produce hydrogen and poly- $\beta$-hydroxybutyric acid by $R$. capsulatus DSM 1710 and they obtained similar results such that total biomass of bacteria in the bioreactor increased in parallel to raising the amount of acetate from $10 \mathrm{mM}$ to 65 $\mathrm{mM}$. In our previous study which was done with 9 $\%$ waste barley hydrolysate, the highest OD value $\left(\mathrm{OD}_{660}\right.$ : 1.78) was attained when using the sugar concentration at the highest concentration $(11 \mathrm{~g} / \mathrm{L}$ sugar) [13]. When compared to previous findings, it can be asserted that the media prepared with 3 $\%$ waste barley hydrolysate is also sufficient to sustain R. sphaeroides O.U.001 and the growth pattern showed the similar tendency when the literature findings were taken into account.

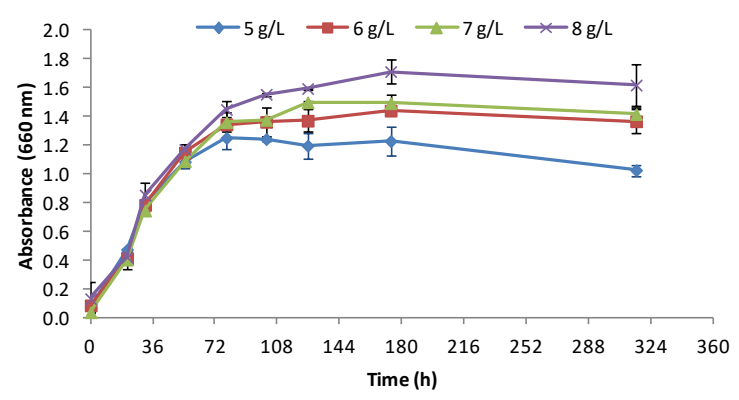

Figure 2. Growth of R. sphaeroides O.U.001 in media prepared by using \% 3 waste barley hydrolysate. The experiment was done duplicate and standard deviations were added.

\subsection{Hydrogen and 5-ALA formation by $R$. sphaeroides O.U.001}

The color and content of the hydrolysate might also affect the hydrogen generation capability of R. sphaeroides O.U.001. For this reason, four different growth media $(5,6,7$ and $8 \mathrm{~g} / \mathrm{L})$ were prepared from $3 \%(\mathrm{w} / \mathrm{v})$ waste barley hydrolysate 
and tested for hydrogen production. The total culture volume was $50 \mathrm{~mL}$ and the gas evolved from the culture was accumulated in the graduated glass tubes. Then, analysis of the collected gas was performed by GC. The percentage (\%) of $\mathrm{H}_{2}$ in collected gas was $81.5,87.3,89.2$ and 80.4 in 5, 6,7 and $8 \mathrm{~g} / \mathrm{L}$ sugar-containing cultures, respectively. Remaining gas was identified as $\mathrm{CO}_{2}$ and air. In Figure 3, total hydrogen accumulation of hydrogen was illustrated. In the preparation of graph, the pure hydrogen amounts were used not the total gas accumulated. Almost the same amount of hydrogen was accumulated in the bioreactors. The highest hydrogen accumulation $\left(0.29 \mathrm{~L} \mathrm{H}_{2} / \mathrm{L}\right)$ was achieved in the bioreactor having initial sugar quantity of $6 \mathrm{~g} / \mathrm{L}$ culture. 0.27 $\mathrm{L} \mathrm{H}_{2} / \mathrm{L}, 0.27 \quad \mathrm{~L} \mathrm{H}_{2} / \mathrm{L}$ and $0.24 \quad \mathrm{~L} \mathrm{H}_{2} / \mathrm{L}$ were produced in the bioreactors having initial sugar quantity of 5,7 and $8 \mathrm{~g} / \mathrm{L}$ culture, respectively. These results are comparable to our previous findings where $0.4 \mathrm{~L} \mathrm{H}_{2} / \mathrm{L}$ was produced in medium having an initial sugar quantity of $11 \mathrm{~g} / \mathrm{L}$ culture (Table 1). The interesting point was that the hydrogen accumulation in higher amount of sugar-containing culture $(8 \mathrm{~g} / \mathrm{L})$ was always lower than that in lower amount of sugar-containing media as opposed to the case observed in growth of bacteria in Figure 2. That is, increase in sugar concentration did not result in an increase in hydrogen production. This may be owing to the darker color of this medium which can prevent the access of light into the bioreactor because 34.48 $\mathrm{mL}$ of hydrolysate was used for the preparation of $8 \mathrm{~g} / \mathrm{L}$ sugar-containing medium while 30.17, 25.86 and $21.55 \mathrm{~mL}$ of hydrolysate were used to make the media having sugar quantities of 7,6 and $5 \mathrm{~g} / \mathrm{L}$ culture, respectively. Moreover, the ammonium and other potentially toxic chemicals like phenols are also found in higher amount in the medium having the highest initial sugar amount of $8 \mathrm{~g} / \mathrm{L}$ culture and this might negatively affect the hydrogen generation capability of the cells in the bioreactor. Light limitation and presence of ammonium seem to be harmless to the cells in terms of their growth but they are thought to be highly effective and restrictive for hydrogen production capability of bacterium. Similar findings were reported by Feng et al. [34] in their study where hydrogen was produced using corn straw (CS) hydrolysate by $R$. capsulatus JL1. They observed that hydrogen yield increased from 1402 to $2966 \mathrm{~mL} / \mathrm{L}$ when the amount of CS hydrolysate was increased from $7.0 \mathrm{~g} \mathrm{CS} / \mathrm{L}$ culture to $16.4 \mathrm{~g} \mathrm{CS} / \mathrm{L}$ culture. However, further increase in substrate concentration resulted in a decrease in hydrogen yield due to the inhibition effect of high amount of hydrolysate. In the current study, 5-ALA production was also investigated; however, 5-ALA was not detected in any of the media. Several possible explanations could be done for situation. Firstly, this may be due to the low sugar concentrations in the media. Probably, the substrate sustained the cells for hydrogen generation and growth but it was not sufficient to produce excess reducing equivalents for the generation of 5-ALA. In our earlier work where higher amounts of substrates were used, $67.4 \mu \mathrm{M}$ of 5-ALA was obtained in the bioreactor having an initial sugar concentration of $9 \mathrm{~g} / \mathrm{L}$ culture [13]. In previous study, levulinic acid and vitamin $\mathrm{B}_{12}$ additions were done to promote 5ALA synthesis but in the present study such additions were not done. This might be reason why 5-ALA was not produced. Finally, the previous study was performed using $9 \%(\mathrm{w} / \mathrm{v})$ waste barley hydrolysate but the present study was done using $3 \%(\mathrm{w} / \mathrm{v})$ waste barley hydrolysate. The two hydrolysates were different in terms of sugar content, ammonium content, element composition, phenol content and transparency. In example, color of the media prepared from $3 \%$ (w/v) waste barley hydrolysate was much darker than the color of the media prepared from $9 \%(\mathrm{w} / \mathrm{v})$ waste barley hydrolysate. These differences might also be the reason why 5-ALA could not be produced in the present study. 


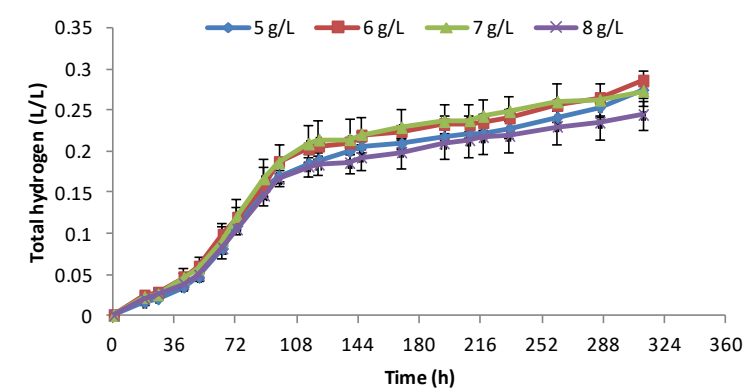

Figure 3. Total accumulation of hydrogen in media prepared by using $3 \%$ waste barley hydrolysate. The experiment was done duplicate and standard deviations were added.

Table 1. Hydrogen generation by $R$. sphaeroides O.U.001 from different carbon sources.

\begin{tabular}{lll}
\hline Initial carbon source & $\begin{array}{c}\mathrm{H}_{2} \text { production } \\
\left(\mathrm{L} \mathrm{H}_{2} / \mathrm{L} \text { culture }\right)\end{array}$ & Ref. \\
\hline Simple sugars, 6 g/L & 0.29 & This \\
& & work \\
Simple sugars, $11 \mathrm{~g} / \mathrm{L}$ & 0.40 & {$[13]$} \\
Acetate, $30 \mathrm{mM}$ & 0.21 & {$[21]$} \\
Malate, $15 \mathrm{mM}$ & 1.97 & {$[21]$} \\
Sucrose, $28 \mathrm{~g} / \mathrm{L}$ & 1.01 & {$[12]$} \\
\hline
\end{tabular}

\section{CONSCLUSION}

Different type of feedstock has been used as carbon source for biological hydrogen production for many years. The important point in these studies is to find the optimum concentration of the substrate. While inadequacy of carbon source leads to lower hydrogen yield, the excess of it leads to inhibition of hydrogen production and cell growth. In this context, in the current study, $\mathrm{pH}$ variations, growth of $R$. sphaeroides O.U.001, biological hydrogen production and 5aminolevulinic acid production were investigated using waste barley as carbon source. Relatively low concentrations of sugar-containing media $(5$, $6,7$ and $8 \mathrm{~g} / \mathrm{L})$ were prepared from $3 \%(\mathrm{w} / \mathrm{v})$ waste barley hydrolysate. The $\mathrm{pH}$ of the cultures did not change significantly during the bioprocess. The initial amounts of sugars in the bioreactors sufficiently sustained cell growth. Similarly, comparable amounts of hydrogen were obtained. However, the 5-ALA was not detected in any of the media. To conclude, $3 \%$ waste barley hydrolysate could also be used for the cultivation and hydrogen generation by $R$. sphaeroides O.U.001.

\section{ACKNOWLEDGEMENTS}

This research was supported by Selçuk University (BAP-12201030). Prof. İnci Eroğlu and Dominic Deo Androga are acknowledged gratefully for their technical support.

\section{REFERENCES}

[1] Aydın H. and İlkılıç C., Air pollution, pollutant emissions and harmfull effects, Journal of Engineering and Technology, 1 (2017) 8-15.

[2] Sharma B. S., Jain S., Khirwadkar P., Kulkarni S., The effects of air pollution on the environment and human health, Indian Journal of Research in Pharmacy and Biotechnology, 1-3 (2013) 391-396.

[3] Das D. and Veziroğlu T. N., Hydrogen production by biological processes: a survey of literature, Int. J. Hydrogen Energy, 26 (2001) 13-28.

[4] Reverberi A. P., Klemeš J. J., Varbanov P. S., Fabiano B., A review on hydrogen production from hydrogen sulphide by chemical and photochemical methods, Journal of Cleaner Production, 136 (2016) 72-80.

[5] Kars G., Biyokütleden biyohidrojen üretimi, Tarım Makinaları Bilimi Dergisi, 8-3 (2012) 265-270.

[6] Özgür E., Mars A. E., Peksel B., Louwerse A., Yücel M., Gündüz U., Claassen P. A. M., Eroğlu İ., Biohydrogen production from beet molasses by sequential dark and photofermentation, Int. J. Hydrogen Energy, 35 (2010) 511-517.

[7] Kars G. and Gündüz U., Towards a super $\mathrm{H}_{2}$ producer: improvements in photofermentative biohydrogen production by genetic manipulations. Int. 
J. Hydrogen Energy, 35 (2010) 66466656.

[8] Kars G., Improvement of biohydrogen production by genetic manipulations in Rhodobacter sphaeroides O.U.001. Biotechnology, Ph.D. Thesis, Middle East Technical University; October 2008.

[9] Sasaki K., Tanaka T., Nishizawa Y., Hayashi M., Production of a herbicide, 5aminolevulinic acid, by Rhodobacter sphaeroides using the effluent waste from an anaerobic digestor, Appl. Microbiol. Biot., 32 (1990) 727-731.

[10] Sasaki K., Watanabe M., Suda Y., Ishizuka A., Noparatnaraporn N., Applications Of Photosynthetic Bacteria For Medical Fields, J. Biosci. Bioeng., 10-5 (2005) 481-488.

[11] Yiğit D. Ö., Gündüz U., Türker L., Yücel M., Eroğlu İ., Identification of byproducts in hydrogen producing bacteria; Rhodobacter sphaeroides O.U.001 grown in the waste water of a sugar refinery. J. Biotechnol., 70 (1999) 125-131.

[12] Kars G. and Alparslan Ü., Valorization of sugar beet molasses for the production of biohydrogen and 5-aminolevulinic acid by Rhodobacter sphaeroides O.U.001 in a biorefinery concept. Int. J. Hydrogen Energy, 38 (2013) 14488-14494.

[13] Kars G. and Ceylan A., Biohydrogen and 5 -aminolevulinic acid production from waste barley by Rhodobacter sphaeroides O.U.001 in a biorefinery concept. Int. J. Hydrogen Energy, 38 (2013) 5573-5579.

[14] Westermann P., Jorgensen B., Lange L., Ahring B. K., Christensen C. H., Maximizing renewable hydrogen production from biomass in a bio/catalytic refinery, Int. J. Hydrogen Energy, 32 (2007) 4135-4141.

[15] Rabelo S. C., Carrere H., Maciel Filho R., Costa A. C., Production of bioethanol, methane and heat from sugarcane bagasse in a biorefinery concept. Bioresour. Technol., 102 (2011) 7887-7895.

[16] Béligon V., Noblecourt A., Christophe G., Lebert A., Larroche C., Fontanille P., Proof of concept for biorefinery approach aiming at two bioenergy production compartments, hydrogen and biodiesel, coupled by an external membrane, Biofuels, 9-2 (2018) 163-174.

[17] Argun H., Gökfiliz P., Karapinar I., Biohydrogen Production Potential of Different Biomass Sources. In: Singh A., and Rathore D. (Eds.). Biohydrogen Production: Sustainability of Current Technology and Future Perspective. New Delhi: Springer, 2017; pp 11-48.

[18] Reginatto V. and Antônio R. V., Fermentative hydrogen production from agroindustrial lignocellulosic substrates, Brazilian Journal of Microbiology, 46-2 (2018) 323-335.

[19] Biebl H. and Pfennig N., Isolation of members of the family Rhodosprillaceae. In: Starr M. P., Stolp H., Trüper H., Balows A., Schlegel H. G. (Eds). The prokaryotes. New York: Springer-Verlag, 1981; pp 267-273.

[20] Koku H., Eroğlu İ., Gündüz U., Yücel M., Türker L., Aspects of the metabolism of hydrogen production by Rhodobacter sphaeroides, Int. J. Hydrogen Energy, 27 (2003) 1315-1329.

[21] Kars G., Gündüz U., Yücel M., Rakhely G., Kovacs K. L., Eroğlu İ., Evaluation of hydrogen production by Rhodobacter sphaeroides O.U.001 and its hupSL deficient mutant using acetate and malate as carbon sources, Int. J. Hydrogen Energy, 34 (2009) 2184-2190.

[22] Akköse S., Gündüz U., Yücel M., Eroğlu İ., Effects of ammonium ion, acetate, and aerobic conditions on hydrogen production and expression levels of nitrogenase genes in Rhodobacter 
sphaeroides O.U.001, Int. J. Hydrogen Energy, 34 (2009) 8818-8827.

[23] Kars G., Gündüz U., Yücel M., Türker L., Eroğlu İ., Hydrogen production and transcriptional analysis of nifD, nifK and hupS genes in Rhodobacter sphaeroides O.U.001 grown in media with different concentrations of molybdenum and iron, Int. J. Hydrogen Energy, 31 (2006) 15361544.

[24] Dubois M., Gilles K. A., Hamilton J. K., Rebers P. A., Smith F., Colorimetric method for determination of sugars and related substances, Anal. Chem., 8 (1956) 350-366.

[25] Mauzerall D. and Granick S., the occurrence and determination of $\mathrm{d}$ aminolevulinic acid and porphobilinogen in urine, J. Biol. Chem., 219 (1956) 435446.

[26] Ceylan A., Biohydrogen and aminolevulinic acid production from waste barley by Rhodobacter sphaeroides. Biology, MSc Thesis, Selçuk University; July 2012.

[27] Liu T., Zhu L., Wei W., Zhou Z., Function of glucose catabolic pathways in hydrogen production from glucose in Rhodobacter sphaeroides, Int. J. Hydrogen Energy, 6016-39 (2014) 42154221.

[28] Pattanamanee W., Chisti Y., Choorit W., Photofermentive hydrogen production by Rhodobacter sphaeroides S10 using mixed organic carbon: effects of the mixture composition, Applied Energy, 157 (2015) 245-254.

[29] Yeşilada Ö., Şık S., Şam M., Treatment of olive oil mill wastewater with fungi, Turk. J. Biol., 23 (1999) 231-240.

[30] Eroğlu E., Gündüz U., Yücel M., Türker L., Eroğlu İ., Photobiological hydrogen production by using olive mill wastewater as a sole substrate source, Int. J. Hydrogen Energy, 29 (2004) 163-171.

[31] Uyar B., Eroğlu İ., Yücel M., Gündüz U., Türker L., Effect of light intensity, wavelength and illumination protocol on hydrogen production in photobioreactors. Int. J. Hydrogen Energy, 32-18 (2007) 4670-4677.

[32] Laurinavichene T. and Tsygankov A., Inoculum density and buffer capacity are crucial for $\mathrm{H}_{2}$ photoproduction from acetate by purple bacteria, Int. J. Hydrogen Energy, 43-41 (2018) 1887318882.

[33]Demiriz B.O., Kars G., Yücel M., Eroğlu İ., Gündüz U., Hydrogen and poly- $\beta$ hydroxybutyric acid production at various acetate concentrations using Rhodobacter capsulatus DSM 1710. Int. J. Hydrogen Energy, 44-32 (2019) 17269-17277.

[34]Feng J., Yang H., Guo L., The photosynthetic hydrogen production performance of a newly isolated Rhodobacter capsulatus JL1 with various carbon sources. Int. J. Hydrogen Energy, 43-30 (2018) 13860-13868. 